ORIGINAL

\title{
Using miglitol at 30 min before meal is effective in hyperinsulinemic hypoglycemia after a total gastrectomy
}

\author{
Jun Shirakawa, Yuko Murohashi, Noriko Okazaki, Shunsuke Yamazaki, Tetsuya Tamura, \\ Tomoko Okuyama, Yu Togashi and Yasuo Terauchi
}

Department of Endocrinology and Metabolism, Graduate School of Medicine, Yokohama-City University, Yokohama 236-0004, Japan

\begin{abstract}
A 45-year-old woman who had undergone total gastrectomy for gastric cancer presented with a history of postprandial hypoglycemic episodes with loss of consciousness after meals. Laboratory findings revealed marked hyperinsulinemia and hypoglycemia after a meal. We first treated the patient with octreotide; however, she was unable to continue the treatment because of adverse effects of the drug, such as nausea and headache. Diazoxide was used next for preventing hyperinsulinemia; however, this was not effective for suppressing the postprandial insulin secretion. Since hypoglycemia following gastrectomy is thought to be caused by rapid delivery of nutrients into the duodenum, we performed a meal tolerance test while varying the timing of administration of miglitol in relation to the meal. Miglitol was administered $30 \mathrm{~min}$ before, just before, or both $30 \mathrm{~min}$ and just before a meal. In the case of administration just before a meal, insulin secretion was suppressed, although hypoglycemia was not prevented. Administration of the drug 30 min before a meal prevented postprandial hypoglycemia by slowing the increase of the blood glucose and serum insulin levels following the meal to a greater degree than administration just before a meal. Miglitol administration both 30 min and just before a meal caused an even smoother increase in blood glucose and serum insulin levels following the meal. In this report, we propose a new therapeutic approach for reactive hypoglycemia after gastrectomy, namely, administration of miglitol 30 min before meals.
\end{abstract}

Keywords: Gastrectomy, Hypoglycemia, Miglitol, Dumping syndrome

POSTPRANDIAL hyperinsulinemic hypoglycemia is often observed in persons who have undergone gastric surgery. Such non-insulinoma hyperinsulinemic hypoglycemia can be severe and cause life-threatening events such as sudden coma in the absence of appropriate treatment $[1,2]$. In some cases of dumping syndrome and other post-prandial hypoglycemia syndromes, dietary modification, with frequent intake of meals or controlled nutritional content of the diet has been shown to resolve the symptoms of postprandial hypoglycemia [3, 4]. However, in cases where dietary modification is ineffective, medical management is often required to prevent the hypoglycemia. Drugs such as $\alpha$-glucosidase inhibitors ( $\alpha$-GIs), calcium channel blockers, somatostatin analogues and diazox-

Submitted Jun. 20, 2014; Accepted Jul. 23, 2014 as EJ14-0290 Released online in J-STAGE as advance publication Aug. 19, 2014 Correspondence to: Yasuo Terauchi, M.D., Ph.D., Department of Endocrinology and Metabolism, Graduate School of Medicine, Yokohama City University, 3-9 Fuku-ura, Kanazawa-ku, Yokohama 236-0004, Japan. E-mail: terauchi-tky@umin.ac.jp ide, and also pancreatectomy, have been applied for the management of postprandial hypoglycemia after gastrectomy [5-12]. However, adverse effects of the drugs and complications of the surgery pose limitations, and no standard treatment for postprandial hypoglycemia has been established yet. Herein, we report successful treatment of a patient who had developed postprandial hyperinsulinemic hypoglycemia following total gastrectomy that was refractory to conventional therapy.

\section{Methods}

\section{Meal tolerance test}

A test meal was selected for the patient according to her daily lifestyle; it contained $303 \mathrm{kcal}, 54.9 \mathrm{~g}$ carbohydrate, $10.5 \mathrm{~g}$ protein, and $4.6 \mathrm{~g}$ fat. The patient took the test meal after a 14-hour fast, and blood samples were collected from an antecubital vein just before intake of the meal (fasting), and at 30, 60, 90, 120, 180 and 240 minutes after the meal intake. Plasma glucose (PG) was measured by the glucose dehydrogenase 
method and the serum insulin and c-peptide levels were measured by the enzyme immunoassay method. If the patient complained of hypoglycemic symptoms or the plasma glucose levels were lower than $50 \mathrm{mg} / \mathrm{dL}$ after intake of the meal, the patient was advised to take $20 \mathrm{~g}$ glucose. Octreotide $25 \mu \mathrm{g}$ was administered subcutaneously twice a day just before the morning and evening meals. Diazoxide $50 \mu \mathrm{g}$ was administered orally 3 times a day after every meal. Miglitol was administered orally as follows; $75 \mathrm{mg}$ just before the test meal, $75 \mathrm{mg}$ $30 \mathrm{~min}$ before the test meal, $50 \mathrm{mg} 30 \mathrm{~min}$ before the test meal, $50 \mathrm{mg} 30 \mathrm{~min}$ before the test meal plus $25 \mathrm{mg}$ just before the test meal, and $25 \mathrm{mg} 30 \mathrm{~min}$ before the test meal plus $50 \mathrm{mg}$ just before the test meal.

\section{Continuous glucose monitoring}

Continuous glucose monitoring (CGM) was performed with iPro $2^{\circledR}$ (Medtronic, USA), according to the manufacturer's instructions. Daily fluctuations of the blood glucose levels were determined based on the mean amplitude of glycemic excursions (MAGE) [13].

\section{Informed consent}

Octreotide, diazoxide and miglitol are not yet approved for use in the treatment of non-insulinoma hypoglycemia in Japan. We informed the subjects about their efficacy and side effects of these drugs and obtained informed consent for their administration.

\section{Case Presentation}

A 45-year-old woman who had undergone a total gastrectomy for advanced gastric cancer 3 years ago (December 2010) and received chemotherapy, presented with a history of weakness, headache, palpitation, sweating, dizziness and significant fatigue developing two to four hours after meals. She was diagnosed as having dumping syndrome and instructed to take 6 small divided meals a day. While the early symptoms of dumping syndrome such as postprandial tachycardia or dizziness improved, the patient continued to suffer from frequent hypoglycemic episodes, with loss of consciousness, developing three to four hours after meals. She measured her blood glucose levels daily at home (self-monitoring of blood glucose (SMBG)), which frequently indicated low blood glucose levels of less than $20 \mathrm{mg} / \mathrm{dL}$. Her hypoglycemic symptoms were limited to the postprandial state. Two years ago, she was admitted to another hospital for postprandial hypo- glycemia, and treated with voglibose, an alpha-glucosidase inhibitor ( $\alpha-\mathrm{GI})$, administered just before meals. Subsequently, miglitol, another $\alpha$-GI, was prescribed at the dose of $25 \mathrm{mg}$ for intake just before a meal in place of voglibose. However, neither $\alpha$-GI could effectively prevent the hypoglycemia and the patient's symptoms persisted. She was therefore admitted to our hospital for further management in December 2013.

On admission, she complained of generalized fatigue and the blood glucose determined with a glucometer was undetectable $(<20 \mathrm{mg} / \mathrm{dL})$. There were no sympathetic nervous manifestations associated with the hypoglycemia. On physical examination, the patient was $167 \mathrm{~cm}$ tall and weighed $41.5 \mathrm{~kg}$, with a body mass index of 15.0. Her blood pressure was $86 / 50 \mathrm{~mm} \mathrm{Hg}$, body temperature $35.2^{\circ} \mathrm{C}$ and pulse 64 beats/min, regular. The thyroid gland was not palpable. There was no peripheral edema. The heart sounds were clear, with no audible murmurs. The breath sounds were clear, and there were no adventitious sounds. The abdomen was flat and soft, and the bowel sounds were normal. The patient had undergone total gastrectomy for scirrhous gastric cancer at the age of 42 years and received adjuvant TS- 1 treatment for 18 months. No signs of residual/recurrent gastric cancer had been observed until date. She had no family history of hypoglycemia, diabetes or cancer. Laboratory examinations (Table 1) revealed a hemoglobin A1c (HbA1c) level of 5.3\%, and her fasting plasma glucose (FPG) level was $81 \mathrm{mg} / \mathrm{dL}$. The 1,5-Anhydroglucitol level was $50.3 \mu \mathrm{U} / \mathrm{mL}$, suggesting postprandial hypoglycemia. Her fasting serum immunoreactive insulin (IRI) and serum C-peptide immunoreactivity (CPR) were $2.6 \mu \mathrm{U} / \mathrm{mL}$ and $1.1 \mathrm{ng} / \mathrm{mL}$, respectively. Serum levels of insulin-like growth factor-1 (IGF-1) and gastrin were $92 \mathrm{ng} / \mathrm{mL}$ and $93 \mathrm{pg} / \mathrm{mL}$, respectively. The serum lactate and pyruvate levels were $4.4 \mathrm{mg} / \mathrm{dL}$ and $0.22 \mathrm{mg} / \mathrm{dL}$, respectively. Serum ketones were slightly elevated in the fasting state. Serum tests for anti-glutamic acid decarboxylase (GAD) and auto-insulin antibodies (IAA) were negative. There was no evidence of renal function impairment or electrolyte imbalance. Hormonal evaluations revealed normal anterior pituitary, thyroid, and adrenal functions. Computed tomography of the abdomen, endoscopic ultrasonography and abdominal MRI revealed no focal abnormalities of the pancreas or other tissues.

We initially performed a meal tolerance test (303 kcal), as described in the Methods section, to evalu- 
Table 1 Laboratory data on admission

\begin{tabular}{lc|lc|lc|lc}
\hline WBC & $40.0 \times 10^{3} / \mu \mathrm{L}$ & glucose & $81 \mathrm{mg} / \mathrm{dL}$ & albumin & $3.9 \mathrm{~g} / \mathrm{dL}$ & serum ketones & $445 \mu \mathrm{mol} / \mathrm{L}$ \\
$\mathrm{RBC}$ & $3.45 \times 10^{4} / \mu \mathrm{L}$ & HbAlc & $5.3 \%$ & LDH & $211 \mathrm{IU} / \mathrm{L}$ & acetoacetate & $122 \mu \mathrm{mol} / \mathrm{L}$ \\
$\mathrm{Hb}$ & $11.2 \mathrm{~g} / \mathrm{dL}$ & IRI & $2.58 \mu \mathrm{U} / \mathrm{mL}$ & AST & $68 \mathrm{U} / \mathrm{L}$ & 3 -hydroxybutyrate & $323 \mu \mathrm{g} / \mathrm{dL}$ \\
$\mathrm{Ht}$ & $33.1 \%$ & CPR & $1.1 \mathrm{ng} / \mathrm{mL}$ & $\gamma-\mathrm{GTP}$ & $23 \mathrm{IU} / \mathrm{L}$ & PRL & $6.5 \mathrm{ng} / \mathrm{mL}$ \\
$\mathrm{Na}$ & $141 \mathrm{mEq} / \mathrm{L}$ & gastrin & $93 \mathrm{pg} / \mathrm{mL}$ & $\mathrm{T}-\mathrm{Bil}$ & $0.8 \mathrm{mg} / \mathrm{dL}$ & ACTH & $28.1 \mathrm{pg} / \mathrm{mL}$ \\
$\mathrm{K}$ & $3.5 \mathrm{mEq} / \mathrm{L}$ & lactate & $4.4 \mathrm{mg} / \mathrm{dL}$ & BUN & $16.0 \mathrm{mg} / \mathrm{dL}$ & Cortisol & $14.8 \mu \mathrm{g} / \mathrm{mL}$ \\
$\mathrm{Cl}$ & $107 \mathrm{mEq} / \mathrm{L}$ & pyruvate & $0.22 \mathrm{mg} / \mathrm{dL}$ & Cre & $0.77 \mathrm{mg} / \mathrm{mL}$ & GH & $1.69 \mathrm{ng} / \mathrm{mL}$ \\
$\mathrm{Ca}$ & $8.6 \mathrm{mg} / \mathrm{dL}$ & IAA & negative & UA & $3.7 \mathrm{mg} / \mathrm{dL}$ & IGF-1 & $92 \mathrm{ng} / \mathrm{mL}$ \\
\hline
\end{tabular}

WBC, white blood cell; RBC, red blood cell; $\mathrm{Hb}$, hemoglobin; $\mathrm{Ht}$, hematocrit; $\mathrm{Na}$, sodium; $\mathrm{Cl}$, chloride; $\mathrm{K}$, potassium; Ca, calcium; IRI, immunoreactive insulin; CPR, C-peptide immunoreactivity; IAA, autoinsulin antibodies; LDH, lactate dehydrogenase; AST, aspartate aminotransferase; $\gamma$-GTP, gamma-glutamyl transpeptidase; T-Bil, total bilirubin; BUN, blood urea nitrogen; Cre, creatinine; UA, uric acid

Table 2 Meal tolerance tests without medication

No medication, exam 1

\begin{tabular}{cccccccc}
\hline $\min$ & 0 & 30 & 60 & 90 & 120 & 180 & 240 \\
\hline $\mathrm{PG}(\mathrm{mg} / \mathrm{dL})$ & 83 & 201 & 246 & 195 & 123 & 52 & $130^{*}$ \\
$\mathrm{IRI}(\mu \mathrm{U} / \mathrm{mL})$ & 4.1 & 320.4 & 757.0 & 341.3 & 95.5 & 17.4 & $93.4^{*}$ \\
$\mathrm{CPR}(\mathrm{ng} / \mathrm{mL})$ & 1.5 & 17.6 & 32.3 & 24.9 & 15.8 & 7.0 & $11.7^{*}$ \\
\hline
\end{tabular}

No medication, exam 2

\begin{tabular}{cccccccc}
\hline $\min$ & 0 & 30 & 60 & 90 & 120 & 180 & 240 \\
\hline $\mathrm{PG}(\mathrm{mg} / \mathrm{dL})$ & 80 & 155 & 228 & 187 & 105 & 31 & $111^{*}$ \\
$\mathrm{IRI}(\mu \mathrm{U} / \mathrm{mL})$ & 4.7 & 158.5 & 701.7 & 719.8 & 160.3 & 22.9 & $98.2^{*}$ \\
$\mathrm{CPR}(\mathrm{ng} / \mathrm{mL})$ & 1.6 & 10.7 & 30.5 & 35.0 & 19.6 & 7.7 & $11.3^{*}$ \\
\hline
\end{tabular}

*: after rescue of hypoglycemia with $20 \mathrm{~g}$ of glucose.

Table 3 Meal tolerance tests with octreotide and diazoxide Octreotide $25 \mu \mathrm{g}$ twice a day, just before meals

\begin{tabular}{cccccccc}
\hline $\min$ & 0 & 30 & 60 & 90 & 120 & 180 & 240 \\
\hline $\mathrm{PG}(\mathrm{mg} / \mathrm{dL})$ & 88 & 167 & 242 & 267 & 221 & 133 & 107 \\
$\mathrm{IRI}(\mu \mathrm{U} / \mathrm{mL})$ & 4.5 & 7.2 & 22.3 & 66.5 & 56.3 & 17.4 & 7.9 \\
$\mathrm{CPR}(\mathrm{ng} / \mathrm{mL})$ & 1.8 & 1.5 & 2.8 & 7.0 & 8.5 & 6.0 & 4.4 \\
\hline
\end{tabular}

Diazoxide $50 \mathrm{mg}$ three times daily, just before meals

\begin{tabular}{cccccccc}
\hline $\min$ & 0 & 30 & 60 & 90 & 120 & 180 & 240 \\
\hline PG $(\mathrm{mg} / \mathrm{dL})$ & 91 & 249 & 274 & 189 & - & $85^{*}$ & $41^{*}$ \\
$\mathrm{IRI}(\mu \mathrm{U} / \mathrm{mL})$ & 3.7 & 456.1 & $>1000.0$ & 434.9 & - & $46.6^{*}$ & $17.3^{*}$ \\
$\mathrm{CPR}(\mathrm{ng} / \mathrm{mL})$ & 1.2 & 20.3 & 43.7 & 26.5 & - & $11.5^{*}$ & $6.2^{*}$ \\
\hline
\end{tabular}

*: after rescue of hypoglycemia with $20 \mathrm{~g}$ of glucose.

ate her hypoglycemia. The fasting IRI and CPR were less than $6.0 \mu \mathrm{U} / \mathrm{mL}$ and $2.0 \mathrm{ng} / \mathrm{mL}$, respectively. Meal loading led to a marked increase of the IRI and CPR to over $700.0 \mu \mathrm{U} / \mathrm{mL}$ and $30.0 \mathrm{ng} / \mathrm{mL}$, respectively, at 60 min, and to hypoglycemia at $180 \mathrm{~min}$ (Table 2). These results clearly indicated that her symptoms were due to reactive hypoglycemia secondary to late dumping. We therefore tested the effect of octreotide, a somatostatin analogue, administered at the dose of $25 \mu \mathrm{g}$ twice a day. Octreotide markedly suppressed the hyperinsu- linemia and prevented postprandial hypoglycemia in the meal tolerance test (Table 3). However, the patient complained of severe nausea and headache, and was forced to discontinue octreotide. She was then prescribed diazoxide, a $\mathrm{K}_{\text {ATP }}$ channel opener, at the dose of $50 \mathrm{mg}$ three times a day. Amazingly, the meal tolerance test showed more severe hyperinsulinemia and hypoglycemia than that under the no-medication condition (Table 3). Furthermore, the drug caused dizziness and had to be discontinued on the third day. She 
Table 4 Meal tolerance tests with miglitol

1) Miglitol $75 \mathrm{mg}$, just before a meal

\begin{tabular}{cccccccc}
\hline $\min$ & 0 & 30 & 60 & 90 & 120 & 180 & 240 \\
\hline $\mathrm{PG}(\mathrm{mg} / \mathrm{dL})$ & 80 & 126 & 121 & 105 & 87 & $77^{*}$ & $79^{*}$ \\
$\mathrm{IRI}(\mu \mathrm{U} / \mathrm{mL})$ & 2.6 & 111.1 & 129.5 & 34.2 & 10.4 & $3.7^{*}$ & $3.1^{*}$ \\
$\mathrm{CPR}(\mathrm{ng} / \mathrm{mL})$ & 1.2 & 7.5 & 12.3 & 7.9 & 5.0 & $2.3^{*}$ & $1.9^{*}$ \\
\hline
\end{tabular}

2) Miglitol $75 \mathrm{mg}, 30 \mathrm{~min}$ before a meal, exam 1

\begin{tabular}{cccccccc}
\hline $\min$ & 0 & 30 & 60 & 90 & 120 & 180 & 240 \\
\hline $\mathrm{PG}(\mathrm{mg} / \mathrm{dL})$ & 81 & 111 & 125 & 102 & 88 & 76 & 77 \\
$\mathrm{IRI}(\mu \mathrm{U} / \mathrm{mL})$ & 4.7 & 74.3 & 208.6 & 43.0 & 17.2 & 4.9 & 3.7 \\
$\mathrm{CPR}(\mathrm{ng} / \mathrm{mL})$ & 1.6 & 6.1 & 14.0 & 8.0 & 5.8 & 2.9 & 2.4 \\
\hline
\end{tabular}

2) Miglitol $75 \mathrm{mg}, 30 \mathrm{~min}$ before a meal, exam 2

\begin{tabular}{cccccccc}
\hline $\min$ & 0 & 30 & 60 & 90 & 120 & 180 & 240 \\
\hline $\mathrm{PG}(\mathrm{mg} / \mathrm{dL})$ & 83 & 101 & 142 & 118 & 92 & 72 & 71 \\
$\mathrm{IRI}(\mu \mathrm{U} / \mathrm{mL})$ & 6.2 & 87.4 & 239.8 & 111.2 & 35.6 & 5.6 & 4.1 \\
$\mathrm{CPR}(\mathrm{ng} / \mathrm{mL})$ & 1.6 & 6.1 & 14.5 & 12.7 & 8.7 & 4.0 & 3.0 \\
\hline
\end{tabular}

3) Miglitol $50 \mathrm{mg}, 30 \mathrm{~min}$ before a meal

\begin{tabular}{cccccccc}
\hline $\min$ & 0 & 30 & 60 & 90 & 120 & 180 & 240 \\
\hline $\mathrm{PG}(\mathrm{mg} / \mathrm{dL})$ & 80 & 81 & 109 & 101 & 70 & 76 & 81 \\
$\mathrm{IRI}(\mu \mathrm{U} / \mathrm{mL})$ & 2.3 & 99.4 & 173.1 & 53.8 & 12.8 & 3.6 & 3.1 \\
$\mathrm{CPR}(\mathrm{ng} / \mathrm{mL})$ & 1.3 & 2.2 & 11.2 & 8.8 & 5.5 & 2.6 & 2.0 \\
\hline
\end{tabular}

4) Miglitol $50 \mathrm{mg}, 30 \mathrm{~min}$ before a meal + miglitol $25 \mathrm{mg}$, just before a meal, exam 1

\begin{tabular}{cccccccc}
\hline $\min$ & 0 & 30 & 60 & 90 & 120 & 180 & 240 \\
\hline $\mathrm{PG}(\mathrm{mg} / \mathrm{dL})$ & 82 & 106 & 134 & 113 & 88 & 82 & 85 \\
$\mathrm{IRI}(\mu \mathrm{U} / \mathrm{mL})$ & 3.4 & 33.3 & 149.9 & 33.7 & 11.2 & 3.2 & 4.0 \\
$\mathrm{CPR}(\mathrm{ng} / \mathrm{mL})$ & 1.1 & 3.8 & 11.1 & 7.4 & 4.8 & 2.3 & 1.8 \\
\hline
\end{tabular}

4) Miglitol $50 \mathrm{mg}, 30 \mathrm{~min}$ before a meal + miglitol $25 \mathrm{mg}$, just before a meal, exam 2

\begin{tabular}{cccccccc}
\hline min & 0 & 30 & 60 & 90 & 120 & 180 & 240 \\
\hline PG $(\mathrm{mg} / \mathrm{dL})$ & 81 & 121 & 96 & 89 & 73 & 74 & 78 \\
IRI $(\mu \mathrm{U} / \mathrm{mL})$ & 3.2 & 51.6 & 109.5 & 26.7 & 7.2 & 3.1 & 3.0 \\
CPR (ng/mL) & 1.4 & 7.5 & 10.7 & 6.9 & 4.1 & 2.1 & 1.8 \\
\hline \multicolumn{7}{l}{ 5) Miglitol $25 \mathrm{mg}, 30 \mathrm{~min}$ before a meal + miglitol $50 \mathrm{mg}$, just before a meal } \\
\hline min & 0 & 30 & 60 & 90 & 120 & 180 & 240 \\
\hline PG (mg/dL) & 78 & 114 & 123 & 112 & 86 & 76 & 78 \\
IRI $(\mu \mathrm{U} / \mathrm{mL})$ & 4.9 & 77.0 & 158.5 & 82.9 & 15.3 & 6.0 & 5.5 \\
CPR (ng/mL) & 1.6 & 7.1 & 15.4 & 12.5 & 7.5 & 3.7 & 2.9 \\
\hline
\end{tabular}

*: after rescue of hypoglycemia with $20 \mathrm{~g}$ of glucose.

had already been given miglitol at the dose of $25 \mathrm{mg}$ just before a meal and it was not effective. Miglitol administered just before breakfast reportedly exerts its activity in the intestine and improves postprandial hyperglycemia even after lunch in subjects with an intact gastrointestinal system [14]. We also reported that administration of miglitol just before a meal and 15 minutes after the start of a meal flattened the fluctuation of the blood glucose and insulin levels in non-diabetic subjects [15]. Therefore, we attempted to treat the patient with miglitol administered at various times in relation to meals. The following dosing protocols were examined, miglitol at 1) $75 \mathrm{mg}$ just before the test meal, 2) $75 \mathrm{mg} 30 \mathrm{~min}$ before the test meal, 3) $50 \mathrm{mg}$
$30 \mathrm{~min}$ before the test meal, 4) $50 \mathrm{mg} 30 \mathrm{~min}$ before the test meal plus $25 \mathrm{mg}$ just before the test meal (divided administration), and 5) $25 \mathrm{mg} 30 \mathrm{~min}$ before the test meal and $50 \mathrm{mg}$ just before the test meal (divided administration). Administration of miglitol at the dose of $75 \mathrm{mg}$ just before the test meal (protocol 1) improved the postprandial hypoglycemia and hyperinsulinemia, but did not prevent fall of the blood glucose level to less than $50 \mathrm{mg} / \mathrm{dL}$ at $150 \mathrm{~min}$ after the meal (Table 4). Interestingly, all of the other dosing protocols (protocols 2, 3, 4 and 5) ameliorated the hypoglycemia in the meal tolerance test (Table 4). The administration at 30 min before the test meal decreased the rate of increase of the serum insulin levels to a greater degree as com- 

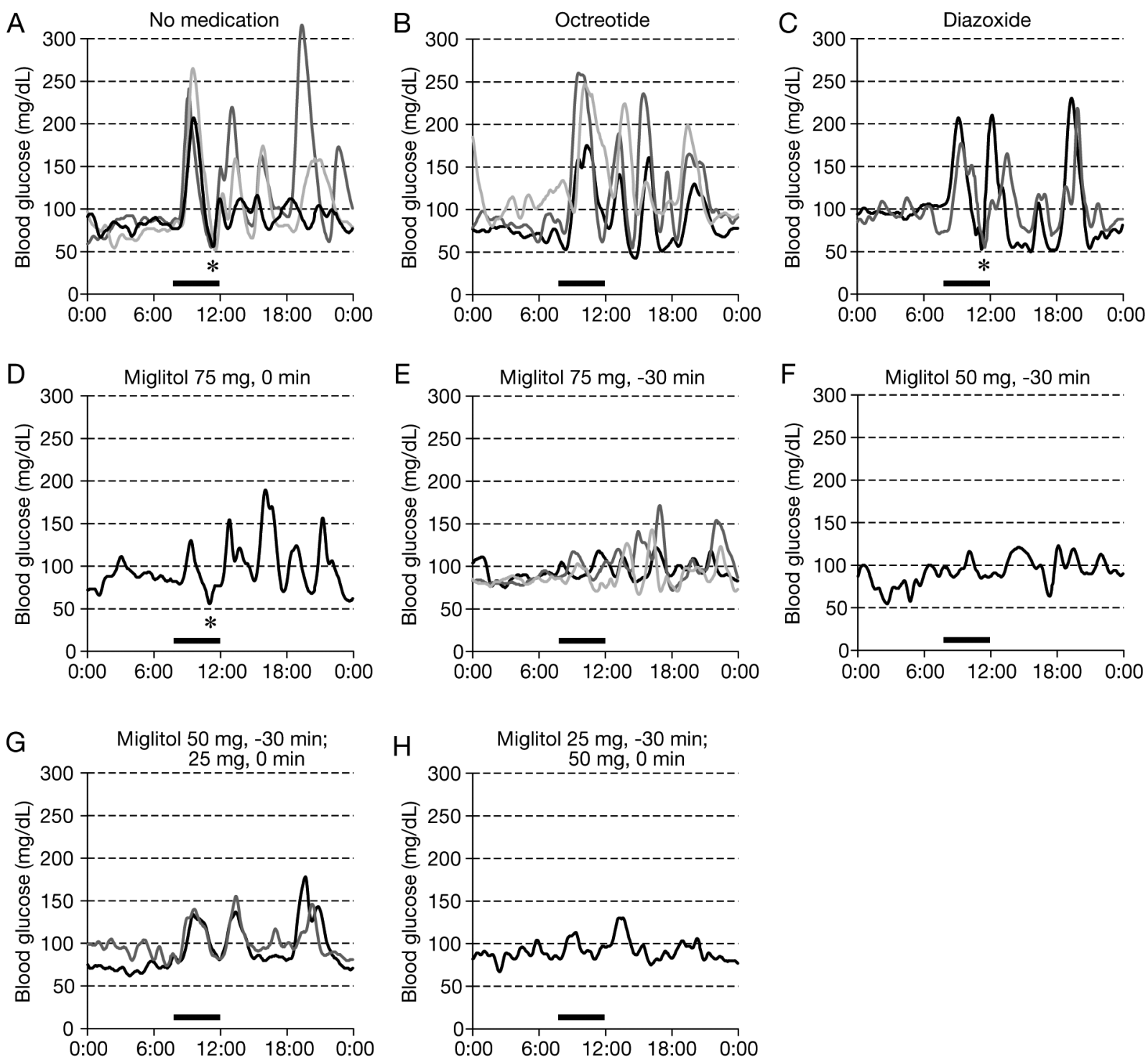

Fig. 1 The daily profiles of continuous glucose monitoring (CGM). The bar from 8:00 am to 12:00 pm represents the meal tolerance test. *: Rescue of hypoglycemia with $20 \mathrm{~g}$ of glucose. (A) No medication. (B) Octreotide $25 \mu \mathrm{g}$ twice a day, just before meals. (C) Diazoxide $50 \mathrm{mg}$ three times daily, just before meals. (D) Miglitol $75 \mathrm{mg}$, just before meals. (E) Miglitol $75 \mathrm{mg}, 30 \mathrm{~min}$ before meals. (F) Miglitol $50 \mathrm{mg}, 30 \mathrm{~min}$ before meals. (G) Miglitol $50 \mathrm{mg}, 30 \mathrm{~min}$ before meals and miglitol $25 \mathrm{mg}$ just before meals. (H) Miglitol $50 \mathrm{mg}, 30 \mathrm{~min}$ before meals and miglitol $25 \mathrm{mg}$, just before meals.

pared to that just before the meal. Furthermore, the divided administrations (protocols 4 and 5) yielded a smoother rise of the serum insulin levels equally and attenuated the peak of insulin levels at $60 \mathrm{~min}$ after the test meal (Table 4). To assess the differences in the glycemic variability associated with the different treatments, we analyzed the results of continuous glucose monitoring (CGM) (Fig. 1) and measured the mean amplitude of glycemic excursion (MAGE) (Table 5). CGM over 24 hours demonstrated that administration of miglitol improved postprandial hyperglycemia and prevented postprandial hypoglycemia in each meal (Fig. 1). Treatment with octreotide and diazoxide also reduced the MAGE levels, although the decrease was smaller than that with miglitol (Table 5). The results of MAGE also demonstrated further improvement of glucose fluctuation by miglitol administration $30 \mathrm{~min}$ before the test meal as compared to that just before the test meal (Table 5). None of the dosing protocols of miglitol was associated with any adverse gastrointesti- 
Table 5 MAGE from the results of CGM

\begin{tabular}{lc}
\hline Protocol & MAGE $(\mathrm{mg} / \mathrm{dL})$ \\
\hline No medication $(\mathrm{n}=4)$ & $78.5 \pm 15.3$ \\
Octreotide $25 \mu \mathrm{g}$, just before a meal, twice a day $(\mathrm{n}=3)$ & $69.8 \pm 19.5$ \\
Diazoxide $50 \mathrm{mg}$ thrice a day, just before meals $(\mathrm{n}=2)$ & $55.4 \pm 15.0$ \\
Miglitol $75 \mathrm{mg}$, just before a meal $(\mathrm{n}=1)$ & 44.5 \\
Miglitol $75 \mathrm{mg}, 30 \mathrm{~min}$ before a meal $(\mathrm{n}=6)$ & $39.8 \pm 17.7$ \\
Miglitol $50 \mathrm{mg}, 30 \mathrm{~min}$ before a meal $(\mathrm{n}=1)$ & 23.4 \\
Miglitol $50 \mathrm{mg}, 30 \mathrm{~min}$ before a meal + miglitol $25 \mathrm{mg}$, just before a meal $(\mathrm{n}=2)$ & $33.4 \pm 10.6$ \\
Miglitol $25 \mathrm{mg}, 30 \mathrm{~min}$ before a meal + miglitol $50 \mathrm{mg}$, just before a meal $(\mathrm{n}=1)$ & 23.4 \\
\hline Data are mean \pm standard deviation $(\mathrm{SD})$. &
\end{tabular}

nal symptoms in the patient.

The patient usually took divided meals 6 times a day, and she requested for medications for each eating. In view of her lifestyle and desire for medication, we finally decided to treat the patient with miglitol taken $30 \mathrm{~min}$ before the main meal $(50 \mathrm{mg})$ and $30 \mathrm{~min}$ before an in-between meal $(25 \mathrm{mg})$. The patient was then discharged, and has not experienced any hypoglycemic episodes or side effects for more than half a year since then.

\section{Discussion}

Postprandial hyperinsulinemic hypoglycemia is one of the complications of gastrectomy. However, no appropriate treatment has been established yet for this condition. Dietary modifications are often applied for the management of hypoglycemia, because of the non-invasive and non-pharmacological nature of this intervention $[3,16]$. Some patients have been treated by pancreatic resection [17], however, this approach often leads to postoperative complications, such as pancreatitis, infection, indigestion and diabetes. Pharmacological treatments have also been applied to treat this type of hypoglycemia. In the present case, dietary modifications did not improve the severe hyperinsulinemic hypoglycemia in the absence of medical treatments, and surgical treatment was not undertaken in view of the patient's overall condition. Therefore, we attempted medical treatment with octreotide, diazoxide, and finally miglitol, to obtain remission of the hypoglycemic events. We did not use calcium channel blockers, because the patient's blood pressure was slightly low. Selective arterial catheterization and calcium stimulation testing were not performed in this case. Nevertheless, islet cell hypertrophy caused by non-insulinoma pancreatogenous hypoglycemia syndrome was ruled out, because the symptoms in this patient began within a few months after surgery.
Octreotide, a somatostatin analogue, is often used for the treatment of hyperinsulinemic hypoglycemia, since somatostatin inhibits insulin secretion from the pancreatic $\beta$ cells via its receptor SSTR5 [18]. In this patient, octreotide significantly reduced the serum insulin levels in the meal tolerance test and prevented hypoglycemia. However, the occurrence of adverse effects necessitated its discontinuation of the drug. Octreotide reportedly suppresses plasma GLP-1 and GIP levels and improves early dumping syndrome [9, 19]. Recently, Smith et al. reported that the incretin effect of GLP-1 is not mediated by the GLP-1 receptor of the pancreatic $\beta$ cells under normoglycemic conditions [20]. We also reported improvement of glycemic control by a GLP-1 receptor agonist through insulin-independent mechanisms [21]. Accordingly, the contribution of the incretins to hyperinsulinemic hypoglycemia remains controversial. Further study is required to confirm the incretin-mediated effects of octreotide on hypoglycemia in late dumping syndrome.

Activation of $\mathrm{K}_{\mathrm{ATP}}$ channels in the $\beta$ cells induces efflux of potassium ions $(\mathrm{K})$ causing hyperpolarization of the cell membrane and inactivation of voltage-dependent calcium channels (VDCC); this suppresses the calcium influx thereby inhibiting insulin release. Successful treatment of post-gastrectomy hypoglycemia by diazoxide, a $\mathrm{K}_{\mathrm{ATP}}$ channel opener, has actually been reported $[10,11]$. In the present patient, however, diazoxide failed to improve the hyperinsulinemia. It is possible that in this patient, the absorption of diazoxide was attenuated due to the gastrectomy, or a $\mathrm{K}_{\mathrm{ATP}}$ channel-independent insulin secretory mechanism was involved in the hyperinsulinemia [22, 23]. Because the symptom of hypoglycemia manifested after total gastrectomy and occurred only after meals, it is highly unlikely that that patient had diazoxide-resistant congenital hyperinsulinism (CHI) [24].

Miglitol inhibits $\alpha$-glucosidase activity in the upper 
part of the small intestine and reduces the rapid postprandial increase of the blood glucose and IRI levels to a greater degree than other $\alpha$-GIs in patients with type 2 diabetes $[25,26]$. It has also reported that miglitol, but not acarbose or voglibose, improves the reactive hypoglycemia caused by late dumping syndrome [6]. However, in this case, the patient had already been treated with miglitol administered just before meals, and her postprandial hypoglycemia had not ameliorated. Excessive insulin secretion in late dumping syndrome is evoked by the sudden increase in blood glucose levels due to the rapid passage of carbohydrates into the small intestine and their subsequent absorption [27]. If this rapid passage is also applied to miglitol, it causes a swift transport of miglitol from upper intestine to the lower intestine before the sufficient inhibition of glucose absorption in upper intestine by miglitol. We hypothesized that the onset of the effect of miglitol administered just before a meal was too late for preclusion of the $\alpha$-glucosidase activity in the upper intestine in patients who have undergone gastric resection. Hence, we administered miglitol $30 \mathrm{~min}$ before meals so as to have the drug begin to act in time with the entry of carbohydrates into the intestine. This prior oral administration resolved the hypoglycemia in our patient by reducing the rate of rise of the serum insulin levels, as expected. The results of MAGE also supported these results in the current case. Glucose variability is thought to be linked to vascular endothelial dysfunction, which in turn is known to be linked to the risk of cardiovascular events [28]. From this viewpoint, miglitol administration $30 \mathrm{~min}$ before a meal might be beneficial for type 2 diabetic patients. Despite its prevention of hypoglycemia, miglitol administration 30 min before meal demonstrated higher serum insulin levels at $60 \mathrm{~min}$ after meal tolerance test, compared to administration just before meal (table 4). These data suggest that factors other than insulin also contribute to the amelioration of hypoglycemia by the administration $30 \mathrm{~min}$ before meal. A variety of intestinal hormones including incretins (both GLP-1 and GIP) exaggerated in patients with dumping syndrome $[29,30]$. Elevation of incretin levels causes hypoglycemia not only by stimulating insulin release but also inhibiting glucagon release. Miglitol increased GLP-1 levels and decreased GIP levels after intake of mixed meal in type 2 diabetes patients [31]. On the other hand, administration of miglitol abrogated both GIP and GLP-1 ele- vations after meal in the patients of insulinoma following total gastrectomy [32]. It is possible that the administration of miglitol at $30 \mathrm{~min}$ before the test meal enhanced glucagon secretion by suppressing the release of incretins. It would be of interest to evaluate the effect of miglitol administration $30 \mathrm{~min}$ before meal on the releases of glucagon, GLP-1, GIP, and other gastrointestinal hormones in subjects who have undergone total gastrectomy in the future.

Interestingly, divided-dose administration of miglitol $30 \mathrm{~min}$ before and just before a meal suppressed the insulin surge either equaled or surpassed that of 30 min before a meal. The peak of serum insulin levels at 60 min after meal and AUC (data not shown) of insulin levels during meal tolerance test were decreased by the divided-dose administration. This was consistent with our previous report in non-diabetic subjects with normal gastrointestinal function [15]. But the advantage of divided-dose administration in preventing hypoglycemia has so far been unclear and this regimen can cause medication noncompliance. The impacts of other $\alpha$-GIs and other timings of administration of miglitol in relation to meal intake were not examined in this patient. Acarbose and voglibose are poorly absorbed and rapidly excreted in the feces, but miglitol is fully absorbed in the gut. The route and timing of excretion of $\alpha$-GIs in patients who have undergone gastric resection may affect the efficacy against hypoglycemia. Recently, it has been shown that miglitol enhanced $\beta 3$-adrenergic signaling in brown adipose tissue $[33,34]$. These reports raised the possibility that miglitol can modulate the activity of sympathetic nervous system. Thus, miglitol administration $30 \mathrm{~min}$ before a meal can be potentially beneficial to other dumping syndromes by preventing early sympathoadrenergic reactions. Therefore, further studies are needed to clarify the merits of this approach.

In conclusion, we succeeded in effectively treating the postprandial hypoglycemia in a patient who had undergone total gastrectomy by miglitol administration $30 \mathrm{~min}$ before meals. Since ileus is a potential side effect of miglitol, this treatment should be employed with care.

\section{Disclosure}

None of the authors have any conflict of interest to declare in association with this research. 


\section{References}

1. Service FJ, Natt N, Thompson GB, Grant CS, van Heerden JA, et al. (1999) Noninsulinoma pancreatogenous hypoglycemia: a novel syndrome of hyperinsulinemic hypoglycemia in adults independent of mutations in Kir6.2 and SUR1 genes. J Clin Endocrinol Metab 84: 1582-1589.

2. Bellini F, Sammicheli L, Ianni L, Pupilli C, Serio M, et al. (1998) Hypoglycemia unawareness in a patient with dumping syndrome: report of a case. $J$ Endocrinol Invest 21: 463-467.

3. Bantle JP, Ikramuddin S, Kellogg TA, Buchwald H (2007) Hyperinsulinemic hypoglycemia developing late after gastric bypass. Obes Surg 17: 592-594.

4. Kellogg TA, Bantle JP, Leslie DB, Redmond JB, Slusarek B, et al. (2008) Postgastric bypass hyperinsulinemic hypoglycemia syndrome: characterization and response to a modified diet. Surg Obes Relat Dis 4: 492499.

5. Valderas JP, Ahuad J, Rubio L, Escalona M, Pollak F, et al. (2012) Acarbose improves hypoglycaemia following gastric bypass surgery without increasing glucagon-like peptide 1 levels. Obes Surg 22: 582-586.

6. Fujita Y, Tamada D, Kozawa J, Kobayashi Y, Sasaki S, et al. (2012) Successful treatment of reactive hypoglycemia secondary to late dumping syndrome using miglitol. Intern Med 51: 2581-2585.

7. Sanke T, Nanjo K, Kondo M, Nishi M, Moriyama Y, et al. (1986) Effect of calcium antagonists on reactive hypoglycemia associated with hyperinsulinemia. Metabolism 35: 924-927.

8. Tulassay Z, Tulassay T, Gupta R, Cierny G (1989) Long acting somatostatin analogue in dumping syndrome. $\mathrm{Br}$ J Surg 76: 1294-1295.

9. Sato D, Morino K, Ohashi N, Ueda E, Ikeda K, et al. (2013) Octreotide improves early dumping syndrome potentially through incretins: a case report. Endocr $J$ 60: 847-853.

10. Spanakis E, Gragnoli C (2009) Successful medical management of status post-Roux-en-Y-gastric-bypass hyperinsulinemic hypoglycemia. Obes Surg 19: 13331334.

11. Thondam SK, Nair S, Wile D, Gill GV (2013) Diazoxide for the treatment of hypoglycaemic dumping syndrome. QJM 106: 855-858.

12. Mathavan VK, Arregui M, Davis C, Singh K, Patel A, et al. (2010) Management of postgastric bypass noninsulinoma pancreatogenous hypoglycemia. Surg Endosc 24: 2547-2555.

13. Service FJ, Molnar GD, Rosevear JW, Ackerman E, Gatewood LC, et al. (1970) Mean amplitude of glycemic excursions, a measure of diabetic instability. Diabetes 19: 644-655.

14. Masuda K, Aoki K, Terauchi Y (2011) Effects of miglitol taken just before or after breakfast on plasma glucose, serum insulin, glucagon and incretin levels after lunch in men with normal glucose tolerance, impaired fasting glucose or impaired glucose tolerance. J Diabetes Investig 2: 435-440.

15. Aoki K, Kato H, Terauchi Y (2007) Divided-dose administration of miglitol just before and 15 minutes after the start of a meal smoothes postprandial plasma glucose excursions and serum insulin responses in healthy men. Endocr J 54: 1009-1014.

16. Wax JR, Heersink D, Pinette MG, Cartin A, Blackstone J (2007) Symptomatic hypoglycemia complicating pregnancy following Roux-en-Y gastric bypass surgery. Obes Surg 17: 698-700.

17. Patti ME, McMahon G, Mun EC, Bitton A, Holst JJ, et al. (2005) Severe hypoglycaemia post-gastric bypass requiring partial pancreatectomy: evidence for inappropriate insulin secretion and pancreatic islet hyperplasia. Diabetologia 48: 2236-2240.

18. Strowski MZ, Parmar RM, Blake AD, Schaeffer JM (2000) Somatostatin inhibits insulin and glucagon secretion via two receptors subtypes: an in vitro study of pancreatic islets from somatostatin receptor 2 knockout mice. Endocrinology 141: 111-117.

19. Myint KS, Greenfield JR, Farooqi IS, Henning E, Holst JJ, et al. (2012) Prolonged successful therapy for hyperinsulinaemic hypoglycaemia after gastric bypass: the pathophysiological role of GLP1 and its response to a somatostatin analogue. Eur J Endocrinol 166: 951-955.

20. Smith EP, An Z, Wagner C, Lewis AG, Cohen EB, et al. (2014) The role of beta cell glucagon-like peptide-1 signaling in glucose regulation and response to diabetes drugs. Cell Metab 19: 1050-1057.

21. Shirakawa J, Tanami R, Togashi Y, Tajima K, Orime K, et al. (2012) Effects of liraglutide on beta-cell-specific glucokinase-deficient neonatal mice. Endocrinology 153: 3066-3075.

22. Seino Y, Miki T, Fujimoto W, Young Lee E, Takahashi $\mathrm{Y}$, et al. (2013) Cephalic phase insulin secretion is KATP channel independent. J Endocrinol 218: 25-33.

23. Takei M, Dezaki K, Ishii H, Nishio S, Sato Y, et al. (2013) A new experimental model of ATP-sensitive $\mathrm{K}(+)$ channel-independent insulinotropic action of glucose: a permissive role of cAMP for triggering of insulin release from rat pancreatic beta-cells. Endocr $J 60$ : 599-607.

24. Henquin JC, Nenquin M, Sempoux C, Guiot $Y$, Bellanne-Chantelot C, et al. (2011) In vitro insulin secretion by pancreatic tissue from infants with diazoxide-resistant congenital hyperinsulinism deviates from model predictions. J Clin Invest 121: 3932-3942.

25. Tsujino D, Nishimura R, Taki K, Morimoto A, Tajima $\mathrm{N}$, et al. (2011) Comparing the efficacy of alpha-glu- 
cosidase inhibitors in suppressing postprandial hyperglycemia using continuous glucose monitoring: a pilot study-the MAJOR study. Diabetes Technol Ther 13: 303-308.

26. Narita T, Yokoyama H, Yamashita R, Sato T, Hosoba M, et al. (2012) Comparisons of the effects of 12-week administration of miglitol and voglibose on the responses of plasma incretins after a mixed meal in Japanese type 2 diabetic patients. Diabetes Obes Metab 14: 283-287.

27. Tack J, Arts J, Caenepeel P, De Wulf D, Bisschops R (2009) Pathophysiology, diagnosis and management of postoperative dumping syndrome. Nat Rev Gastroenterol Hepatol 6: 583-590.

28. Monnier L, Mas E, Ginet C, Michel F, Villon L, et al. (2006) Activation of oxidative stress by acute glucose fluctuations compared with sustained chronic hyperglycemia in patients with type 2 diabetes. JAMA 295: 1681-1687.

29. Gebhard B, Holst JJ, Biegelmayer C, Miholic J (2001) Postprandial GLP-1, norepinephrine, and reactive hypoglycemia in dumping syndrome. Dig Dis Sci 46: 19151923.

30. Lawaetz O, Blackburn AM, Bloom SR, Aritas Y, Ralphs
DN (1983) Gut hormone profile and gastric emptying in the dumping syndrome. A hypothesis concerning the pathogenesis. Scand J Gastroenterol 18: 73-80.

31. Narita T, Katsuura Y, Sato T, Hosoba M, Fujita H, et al. (2009) Miglitol induces prolonged and enhanced glucagon-like peptide- 1 and reduced gastric inhibitory polypeptide responses after ingestion of a mixed meal in Japanese Type 2 diabetic patients. Diabet Med 26: 187188.

32. Sato T, Narita T, Hosoba M, Kakei M, Nanjo H, et al. (2010) A case of insulinoma following total gastrectomy--effects of an alpha-glucosidase inhibitor on suppressing GIP and GLP-1 elevations. Diabetes Res Clin Pract 88: e4-6.

33. Sasaki T, Shimpuku M, Kitazumi T, Hiraga H, Nakagawa Y, et al. (2013) Miglitol prevents diet-induced obesity by stimulating brown adipose tissue and energy expenditure independent of preventing the digestion of carbohydrates. Endocr J 60: 1117-1129.

34. Sugimoto S, Nakajima H, Kodo K, Mori J, Matsuo K, et al. (2014) Miglitol increases energy expenditure by upregulating uncoupling protein 1 of brown adipose tissue and reduces obesity in dietary-induced obese mice. Nutr Metab (Lond) 11: 14. 